\title{
Effects of dietary fibre and tannins from apple pulp on the composition of faeces in rats
}

\author{
BY L. BRAVO, F.SAURA-CALIXTO* AND I. GONI \\ Instituto de Nutricion y Bromatologia, CSIC-UCM, Facultad de Farmacia, Universidad \\ Complutense, 28040 Madrid, Spain
}

(Received 4 December 1990 - Accepted 5 July 199I)

\begin{abstract}
The present study was undertaken to explore the effect of apple pulp on weight and composition of faeces. This material is rich in dietary fibre (DF;620 $\mathrm{g}$ dry matter $/ \mathrm{kg}$ ) and contains appreciable amounts of polyphenols. Recent reports indicate that both condensed tannins (CT) and soluble polyphenols form cross-links with protein and inhibit digestive enzymes, affecting the protein digestibility, and may produce a stimulation of endogenous nitrogen excretion. Two groups of male Wistar rats were fed on either a control diet free of DF or a diet containing $100 \mathrm{~g}$ apple pulp DF/ $\mathrm{kg}$ during $7 \mathrm{~d}$ after a $4 \mathrm{~d}$ adaptation period. Body-weight and food intake were monitored daily and faeces and urine were collected once daily. DF, water content and polyphenolic compounds were measured in faeces, and $\mathbf{N}$ content in both faeces and urine. Faecal weight increased in the fibre group by 280 and $240 \%$ when compared with wet and dry faecal weights of animals fed on the fibre-free diet. Soluble dietary fibre (SDF) excreted in faeces was $10.9 \%$ of the SDF ingested, which suggested a low resistance to fermentation of this fraction. Of the insoluble DF, $43 \%$ of the ingested fibre was fermented. Polyphenols were degraded in the intestinal tract. Of the ingested $\mathrm{CT}, 68.6 \%$ was recovered in faeces, while the soluble polyphenols were extensively degraded $(85.7 \%$ of that ingested). On the other hand, a higher faecal $\mathbf{N}$ excretion was observed for the fibre-fed group, suggesting a decrease in the digestibility of the dietary protein and lower apparent digestibility and $\mathrm{N}$ balance indices.
\end{abstract}

Apple pulp: Dietary fibre: Faeces composition: Polyphenols

The relative amounts of insoluble and soluble fractions in dietary fibre (DF) are important due to their physiological effects. Water-insoluble fibre appears to be less available for fermentation in the large bowel than water-soluble fibre. The bulking effect is more pronounced with insoluble DF (IDF) that is resistant to degradation, and leaves a substantial amount of water-binding fibre in the colon. On the other hand, water-soluble types of DF (SDF) have significant effects on bile acids, cholesterol and glucose metabolism (Nyman \& Asp, 1985).

Cereals are high in insoluble fibre and their contribution to the DF intake in European countries is $35-60 \%$, while fruit only contributes 7-15\% (Bingham, 1985, 1987). Several authors have recommended an increase in the consumption of fruit and vegetables since these products are richer in soluble and fermentable fibres than cereals (Spiller, 1986; Eastwood, 1987).

Apple pulp is a typical source of DF (Goñi et al. 1989; Fibre-90, 1990). It contains condensed tannins (CT)-proanthocyanidin polymers and soluble polyphenols, both of which form effective cross-links with protein and inhibit digestive enzymes, thereby affecting protein digestibility (Kumar \& Singh, 1984; Oh et al. 1985). In vitro these two effects induce significant amounts of non-digested protein and CT in the dietary fibre residues of carob

* For reprints. 
Table 1. Composition of diets $(\mathrm{g} / \mathrm{kg}$ dry diet)

\begin{tabular}{lcc}
\hline \hline Ingredients & $\begin{array}{c}\text { Fibre-free } \\
\text { diet }\end{array}$ & $\begin{array}{c}\text { Fibre } \\
\text { diet }\end{array}$ \\
\hline Lasein +6 g DL-methionıne & 150 & 150 \\
Sucrose & 100 & 100 \\
Olive and sunflower oil & 50 & 50 \\
Mineral mixture* & $38 \cdot 7$ & $38 \cdot 7$ \\
Vitamin mixturet & 11.9 & 11.9 \\
Wheat starch & 620 & 520 \\
Anple-pulp fibre & - & 100 \\
\hline
\end{tabular}

* Contained (g/kg diet): $\mathrm{CaCO}_{3} 10 \cdot 0, \mathrm{KHCO}_{3} 6 \cdot 1, \mathrm{NaH}_{2} \mathrm{PO}_{4} 2 \cdot 26, \mathrm{KH}_{2} \mathrm{PO}_{4} 8 \cdot 2, \mathrm{CaHPO}_{4} 6 \cdot 8, \mathrm{MgSO}_{4} .7 \mathrm{H}_{2} \mathrm{O}$ $2 \cdot 25, \mathrm{MgCO}_{3} 0 \cdot 77, \mathrm{FeSO}_{4} .7 \mathrm{H}_{2} \mathrm{O} 0 \cdot 199, \mathrm{MnSO}_{4} . \mathrm{H}_{2} \mathrm{O} 0 \cdot 17, \mathrm{ZnCO}_{3} 0 \cdot 026, \mathrm{NaF} 0 \cdot 0002, \mathrm{KI} 0 \cdot 0002, \mathrm{Na}_{2} \mathrm{CrO}_{4} 0.001$, $\mathrm{Na}_{2} \mathrm{SeO}_{3} .5 \mathrm{H}_{2} \mathrm{O} 0 \cdot 0002, \mathrm{CuSO}_{4} \cdot 5 \mathrm{H}_{2} \mathrm{O} 0.025$.

$\dagger$ Contained $(\mathrm{mg} / \mathrm{kg}$ diet): pteroylmonoglutamic acid $1 \cdot 11$, niacine $22 \cdot 22$, calcium pantothenate 8.88 , riboflavin $3 \cdot 33$, thiamin $4 \cdot 44$, pyridoxin 6.66 , cyanocobalamine 0.005 , choline $1111 \cdot 11$, retinol $8 \cdot 88$, cholecalciferol $11 \cdot 11$, menadione 0.055, $\alpha$-tocopherol 33.33 (Nyman \& Asp, 1982).

pods, grapes and apple pulp after enzymic treatments with heat-stable amylase $(E C$ 3.2.1.1), protease and amyloglucosidase (EC 3.2.1.3) (Saura-Calixto, 1988; Goñi et al. 1989; Saura-Calixto et al. 1991). Nevertheless, the increase in the excretion of faecal nitrogen may also be due to the stimulation of endogenous $\mathrm{N}$ production by the polyphenolic compounds (Butler, 1989; Shahkhalili et al. 1990). Foods containing CT have been reported to depress the activity of digestive enzymes and increase $\mathrm{N}$ excretion in rats (Griffiths \& Moseley, 1980; Eggum et al. 1983; Horigome et al. 1988; Shahkhalili et al. 1990).

On the other hand, DF may also affect faecal protein excretion, decreasing dietary protein digestibility (Gallaher \& Schneeman, 1986) and affecting endogenous N metabolism (Stephen \& Cummings, 1980; Fairweather-Tait et al. 1983). The effects of apple-pulp DF on the weight and composition of faeces in rats is reported in the present paper, which also considers the fermentation of fibre constituents as well as the presence of faecal CT and protein. In terms of faecal bulking capacity and fermentability of fibre, the rat model has been shown to correlate with human studies (Nyman et al. 1986).

\section{MATERIALS AND METHODS}

\section{Animals and diets}

Male Wistar rats weighing 62 (SD) $1 \mathrm{~g}$ were randomly divided into two groups of ten. The animals were put into individual metabolism cages and kept on a normal $12 \mathrm{~h}$ light-dark cycle with constant air recirculation. Room temperature was kept between 21 and $22^{\circ}$. Both groups received a powdered semi-synthetic diet prepared in the laboratory. Diet composition is given in Table 1. Both diets were similar, but the starch in the fibre-free basal diet was replaced with apple pulp to supply DF. The fibre source was a concentrate of apple pulp containing peels and seeds obtained after ethanolic washing with ethanol $(960 \mathrm{ml} / \mathrm{l})$. The DF composition of apple pulp is described in Table 2. Food and water were available ad lib. Body-weight and food intake were monitored daily.

After $4 \mathrm{~d}$ adaptation to diet and cages, urine and faeces were collected daily during a $7 \mathrm{~d}$ experimental period. Urine was collected in chlorhydric acid $(5 \mathrm{ml} / \mathrm{l})$ and analysed for $\mathrm{N}$. Faeces were removed once daily, weighed and frozen at $-20^{\circ}$, then lyophilized, weighed 
Table 2. Dietary fibre $(D F)$ content of the apple-pulp fibre $(\mathrm{g} / \mathrm{kg}$ dry matter $)$

(Mean values and standard deviations for three determinations)

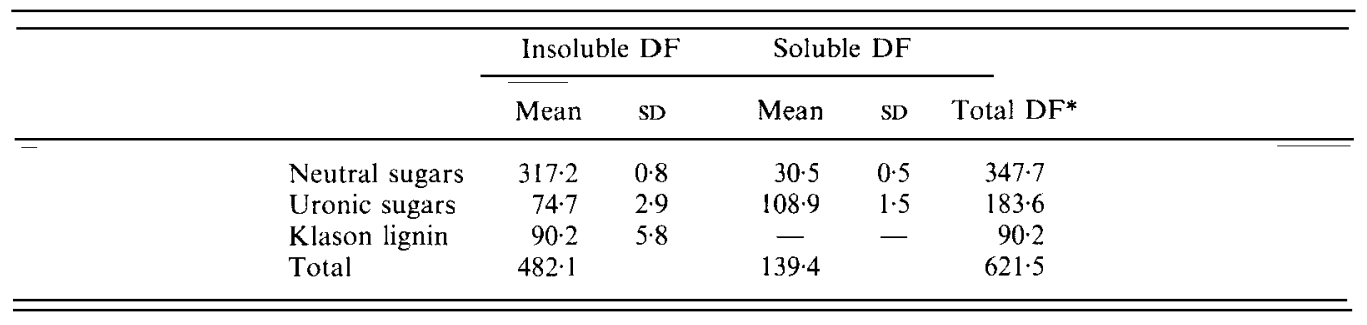

* Total DF calculated as insoluble DF plus soluble DF

again and milled to a particle size less than $0.5 \mathrm{~mm}$. N, DF, uronic acids, neutral sugars and soluble and condensed polyphenol analyses were performed on the mixed samples from the whole experimental period.

\section{Analytical methods}

$D F$. The soluble and insoluble DF fractions in food and faeces were measured following the Association of Official Analytical Chemists' method (Prosky et al. 1988).

A $1 \mathrm{~g}$ sample was successively treated with heat-stable $\alpha$-amylase $\left(100^{\circ}, \mathrm{pH} 6,30 \mathrm{~min}\right)$, protease $\left(60^{\circ}, \mathrm{pH} 7.5,30 \mathrm{~min}\right)$ and amyloglucosidase $\left(60^{\circ}, \mathrm{pH} 4.5,30 \mathrm{~min}\right)$. Then it was filtered and washed with distilled water, ethanol $(960 \mathrm{ml} / 1)$ and acetone. The residue corresponded to IDF. Filtrate and washing water were saved and dialysed with distilled water for $48 \mathrm{~h}$ at room temperature before freeze-drying and weighing. This fraction corresponded to SDF.

After acid-hydrolysis of the IDF residue ( $12 \mathrm{M}$-sulphuric acid, $30^{\circ}, 1 \mathrm{~h}$ and dilution to $1 \mathrm{M}$ $\mathrm{H}_{2} \mathrm{SO}_{4}, 100^{\circ}, 1.5 \mathrm{~h}$ ), neutral sugars and uronic acids were assayed in the filtrate. The SDF residue was solubilized with distilled water and also assayed for neutral sugars and uronic acids.

After the previously described acid treatment of the IDF residue, lignin in the form of Klason lignin (KL) was determined gravimetrically.

The spectrophotometric analysis of the neutral sugars used anthrone-thiourea as reagent and glucose as standard (Southgate, 1976). Uronic acids determination was performed by the Scott (1979) method with galacturonic acid as standard and 3,5-dimethylphenol as reagent.

Polyphenolic compounds. The CT content was spectrophotometrically assayed in food and faeces by reading absorbance at $550 \mathrm{~nm}$ of the anthocyanidin solutions obtained after treating the samples with hydrochloric acid $\left(50 \mathrm{ml} / \mathrm{l}\right.$ ) butanol for $3 \mathrm{~h}$, at $100^{\circ}$ (Reed et al. 1982). Carob-pod CT, supplied by Nestlé SA, were used as standard.

Soluble polyphenols were assayed as flavonols after extraction with distilled water $\left(60^{\circ}\right.$, 30 min, twice) according to the Swain method (Swain \& Hillis, 1959), using vanillin as reagent and $\mathrm{D}$-catechin as standard.

$N$ determination. Diets, urine and faeces were analysed for total $\mathrm{N}$ by the Kjeldahl method, using concentrated $\mathrm{H}_{2} \mathrm{SO}_{4}$ at $350^{\circ}$, with selenium as catalyst (Tecator Kjeltec equipment). Crude protein was calculated as $\mathrm{N} \times 6.25$.

Calculation of digestibility and biological value. From the analysis of the $\mathrm{N}$ content in faeces and urine, the digestive efficiency index (apparent digestibility coefficient) and metabolic efficiency index ( $\mathrm{N}$ balance) were calculated according to the Thomas-Mitchell equations (Mitchell, 1923-24). 
Table 3. Effect of apple-pulp dietary fibre on growth and food intake of rats* (Mean values and standard deviations)

\begin{tabular}{|c|c|c|c|c|c|c|}
\hline \multirow[b]{2}{*}{ Dietary group } & \multicolumn{2}{|c|}{ Initial wt $(\mathrm{g})$} & \multicolumn{2}{|c|}{ Wt increase $(\mathrm{g})$} & \multicolumn{2}{|c|}{$\begin{array}{l}\text { Total food intake } \\
\text { (g dry matter) }\end{array}$} \\
\hline & Mean & SD & Mean & SD & Mean & SD \\
\hline Fibre-free & $63 \cdot 54$ & $2 \cdot 33$ & $48 \cdot 30$ & $3 \cdot 26$ & $78 \cdot 24$ & $4 \cdot 65$ \\
\hline Fibre & $62 \cdot 98$ & $1 \cdot 26$ & $46 \cdot 52$ & $4 \cdot 36$ & $83 \cdot 86$ & $5 \cdot 21$ \\
\hline
\end{tabular}

* For details of diets and procedures, see Tables 1 and 2 and pp. $464-465$.

Table 4. Effect of apple-pulp dietary fibre on stool weight and water content of faeces of rats $\dagger$

(Mean values and standard deviations)

\begin{tabular}{|c|c|c|c|c|c|c|c|c|}
\hline \multirow[b]{3}{*}{ Dietary group } & \multirow{2}{*}{\multicolumn{2}{|c|}{$\begin{array}{l}\text { Total stool } \\
\text { wt }(\mathrm{g} / 7 \mathrm{~d})\end{array}$}} & \multirow{2}{*}{\multicolumn{2}{|c|}{$\begin{array}{c}\text { Total dry stool } \\
\text { wt }(\mathrm{g} / 7 \mathrm{~d})\end{array}$}} & \multicolumn{4}{|c|}{ Water content of faeces } \\
\hline & & & & & \multicolumn{2}{|c|}{$\mathrm{g} / \mathrm{kg}$} & \multicolumn{2}{|c|}{$\mathrm{g} / 7 \mathrm{~d}$} \\
\hline & Mean & $\mathrm{SD}$ & Mean & SD & Mean & SD & Mean & SD \\
\hline Fibre-free & $2 \cdot 81$ & $0 \cdot 54$ & $2 \cdot 11$ & $0 \cdot 30$ & $225 \cdot 7$ & $45 \cdot 8$ & $0 \cdot 70$ & 0.24 \\
\hline Fibre & $10 \cdot 71^{* * *}$ & $0 \cdot 90$ & $7 \cdot 32^{* * *}$ & 0.25 & $317 \cdot 1^{*}$ & $56 \cdot 3$ & $3 \cdot 39 * *$ & 0.99 \\
\hline
\end{tabular}

Mean values were significantly different from those for fibre-free diet: ${ }^{*} P<0.05 ;{ }^{* *} P<0.01$; $^{* * *} P<0.005$.

$\dagger$ For details of diets and procedures, see Tables 1 and 2 and pp. 464-465.

Statistics. The results were tested for significance using the two-tailed Student's $t$ test (Snedecor \& Cochran, 1987).

\section{RESULTS}

The addition of DF affected neither the ponderal growth nor the mean food intake of the animals during the experimental period, as shown in Table 3. The weight increase was similar in both groups ( 48.3 and $46.5 \mathrm{~g} / 7 \mathrm{~d}$ in the control and test groups respectively), and no significant differences were found in the total food intake when dietary fibre was added to the basal diet.

\section{Faecal bulking}

The addition of apple pulp as DF caused a significant increase in both wet and dry faecal weights, as shown in Table 4 . In the fibre-fed rats, the weight of faeces increased by 280 and $240 \%$ respectively compared with the wet and dry faecal weights of the animals fed on the fibre-free control diet. The water content of faeces was significantly higher in the rats fed on the apple-pulp fibre $(3.39 \mathrm{~g} / 7 \mathrm{~d})$ than in those fed on the fibre-free diet $(0 \cdot 70 \mathrm{~g} / 7 \mathrm{~d})$.

\section{Fermentation of DF constituents and polyphenol degradation}

DF and polyphenol intake and excretion are detailed in Table 5. The small but detectable amounts of DF that appeared in the control diet probably came from indigestible starch or, to a lesser degree, from impurities of the elements used to prepare the diet (Nyman \& Asp, 1982). The phenolic compounds present in the fibre-containing diet are constituents 
Table 5. Intake and faecal excretion of apple-pulp dietary fibre and polyphenols $(g / 7 d)$ by rats*

(Mean values and standard deviations)

\begin{tabular}{|c|c|c|c|c|c|c|c|c|}
\hline \multirow{3}{*}{ Dietary group... } & \multicolumn{4}{|c|}{ Intake } & \multicolumn{4}{|c|}{ Excretion } \\
\hline & \multicolumn{2}{|c|}{ Fibre-free } & \multicolumn{2}{|c|}{ Fibre } & \multicolumn{2}{|c|}{ Fibre-free } & \multicolumn{2}{|c|}{ Fibre } \\
\hline & Mean & SD & Mean & SD & Mean & SD & Mean & SD \\
\hline \multicolumn{8}{|l|}{ SDF : } & - \\
\hline Sugars & 0.52 & 0.03 & 1.06 & 0.07 & 0.04 & 0.01 & $0 \cdot 13$ & 0.02 \\
\hline Uronic acids & 0.08 & 0.00 & $0 \cdot 86$ & 0.05 & $0 \cdot 003$ & $0 \cdot 00$ & $0 \cdot 08$ & $0 \cdot 03$ \\
\hline \multicolumn{9}{|l|}{ IDF : } \\
\hline Sugars & 0.25 & 0.01 & $3 \cdot 05$ & 0.19 & 0.04 & 0.01 & $1 \cdot 15$ & $0 \cdot 15$ \\
\hline Uronic acids & 0.08 & 0.00 & $0 \cdot 40$ & $0-03$ & 0.002 & 0.00 & 0.14 & 0.02 \\
\hline Klason lignin & - & - & 1.53 & $0 \cdot 10$ & 一 & - & $1 \cdot 55$ & 0.05 \\
\hline Condensed tannins & - & - & 0.51 & 0.03 & - & - & 0.35 & 0.06 \\
\hline Soluble polyphenols & - & - & $0 \cdot 014$ & 0.001 & 一 & - & 0.002 & $0.00 \mathrm{I}$ \\
\hline
\end{tabular}

TDF, total dietary fibre; SDF, soluble dietary fibre; IDF, insoluble dietary fibre.

* For details of diets and procedures, see Tables 1 and 2 and pp. 464 465.

$\uparrow$ TDF calculated as IDF + SDF.

Table 6. Degradation of dietary undigestible compounds in rats fed on apple-pulp-fibre diet $^{*}$

\begin{tabular}{|c|c|c|c|}
\hline \multirow[b]{2}{*}{ Indigestible compounds } & \multicolumn{3}{|c|}{ Faecal excretion } \\
\hline & Intake $(\mathrm{g} / 7 \mathrm{~d})$ & $g / 7 d$ & $\%$ of intake \\
\hline Soluble dietary fibret & 1.92 & 0.21 & $10 \cdot 94$ \\
\hline Insoluble dietary fibre & 4.98 & $2 \cdot 85$ & $57 \cdot 23$ \\
\hline Total dietary fibre $\$$ & $6 \cdot 90$ & 3.06 & $44 \cdot 35$ \\
\hline Condensed tannins & 0.51 & 0.35 & $68 \cdot 63$ \\
\hline Soluble polyphenols & 0.014 & 0.002 & $14 \cdot 29$ \\
\hline
\end{tabular}

* For details of diets and procedures, see Tables 1 and 2 and pp. 464465 .

$\dagger$ Defined as sugars + uronic acids.

$\ddagger$ Defined as sugars + uronic acids + Klason lignin.

$\S$ Calculated as IDF $+\mathrm{SDF}$.

of the apple-pulp fibre. No phenolics were found in the control diet. The addition of applepulp fibre to the diet provided $6.9 \mathrm{~g}$ total dietary fibre (TDF) and $0.52 \mathrm{~g}$ polyphenolic compounds during the experimental period.

As can be seen from Table 5, both DF and polyphenols were extensively degraded in the intestinal tract. Except for KL, the neutral and acidic polysaccharides (expressed as sugars and uronic acids respectively) of both IDF and SDF fractions were thoroughly fermented. An appreciable degradation of CT and soluble polyphenols was also observed.

As shown in Table 6, SDF excreted in faeces was $10.9 \%$ of the ingested SDF, indicating low resistance to fermentation by this fraction. Both sugars and uronic acids showed similar degree of fermentability $(87.74$ and $90.70 \%$ respectively; Table 5$)$.

For IDF, $43 \%$ of the ingested fibre was fermented; this was similar to the individual values for sugars and uronic acids in the ingested IDF (Table 5). The KL fraction of the 
IDF residue was totally resistant to bacterial degradation, which is in agreement with findings of earlier studies in rats (Nyman \& Asp, 1982).

CT were partially degraded in the intestinal tract, since only $68.6 \%$ of the ingested CT was recovered in faeces (Table 6). A high percentage of the soluble polyphenols was degraded ( 85.7 of that ingested).

\section{Protein excretion}

Protein intake, faecal and urinary $\mathrm{N}$ excretion, and apparent protein digestibility and $\mathrm{N}$ balance indices are given in Table 7 . Protein intake did not differ significantly between the control and the fibre-fed animals. Faecal $\mathbf{N}$ excretion was significantly increased when dietary fibre was added to the diet, and, consequently, the apparent digestibility index was lower than in the control group. The urinary $\mathrm{N}$ excretion was not affected by the presence of DF in the diet.

\section{DISCUSSION}

The addition of DF to the diet did not affect either the ponderal growth or the food intake of the animals during the experimental period. In longer experiments ( 7 weeks), Park \& Harrold (1983) reported a linear increase in the food intake when fibre levels were increased and the energy intake remained the same, although no differences in the growth rate of the rats were found. In contrast, Nomani et al. (1979) reported a higher weight gain in rats fed on different fibre diets with a high energy level than in those fed on a non-fibre diet. Nevertheless, weight gain was not significantly different when the energy level was lower.

The presence of CT in the test diet $(6 \mathrm{~g} / \mathrm{kg}$ dry matter) did not influence the growth rate or the food intake in our experimental conditions. A decrease in the growth rate of immature rats has been reported with higher levels of dietary CT, although food intake did not decrease (Würsch, 1979; Butler, 1989).

Faecal wet and dry weights were significantly increased when DF was added to the diet. These results were very similar to those obtained by Nyman et al. (1990) with vegetables with high fibre contents (carrots, rutabagas, peas, Brussel sprouts and green beans) under similar experimental conditions, as well as with purified pectins and sugar-beet fibre (Nyman \& Asp, 1982).

As is well known, the capacity of fibre to increase faecal bulking is more pronounced with DF that is resistant to degradation in the intestine, leaving a substantial amount of waterbinding fibre, than with easily fermented DF (Nyman \& Asp, 1982). However, fermentable fibre materials such as fruits and vegetables provide a carbohydrate substrate in the large intestine which supplies the energy for the growth of colonic microflora (Stephen \& Cummings, 1980). Therefore, increasing the supply of these materials in the diet stimulates microbial growth and results in an increased faecal bacterial mass, which is able to retain water and contributes to the faecal bulking by itself.

These facts might explain the high dry stool weight in the rats fed on the apple-pulp DF $(1.53 \mathrm{~g} / \mathrm{d})$; larger than the values found when wheat bran was the DF source $(1.06 \mathrm{~g} / \mathrm{d}$; Nyman \& Asp, 1982). The reason might be that this apple-pulp fibre was rich in unfermentable DF ( $482 \mathrm{~g} / \mathrm{kg}$ dry matter, Table 2$)$, but also had a considerable amount of SDF (fermentable; $140 \mathrm{~g}$ dry matter $/ \mathrm{kg}$ ). Furthermore, the water content of faeces was, as expected, significantly higher in the rats fed on the apple-pulp diet than in those fed on the fibre-free diet. Both unfermentable and fermentable fibre fractions contributed to the amount of water held.

With regard to DF fermentation, SDF was highly fermented, since only $10.9 \%$ of the ingested SDF was recovered in faeces (Table 6), whereas IDF was notably more resistant, with only $42.8 \%$ of the ingested IDF being fermented. Approximately $90 \%$ of the soluble 


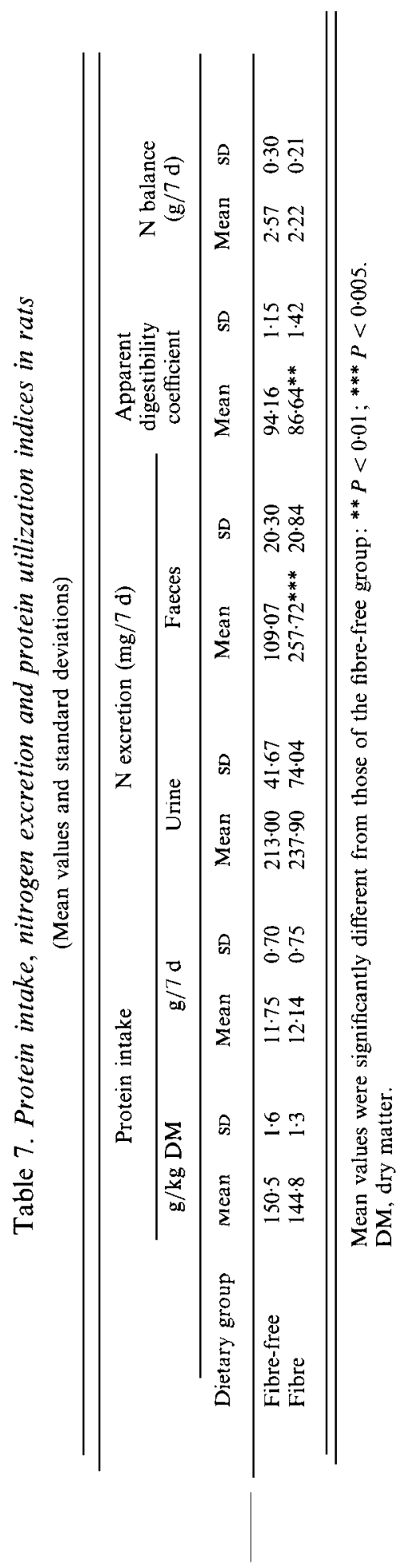


pectins present in the SDF fraction were fermented. Insoluble pectic substances are less available to the bacterial mass because they are cell wall constituents and are associated with other fibre components; the fermentation of these substances in our samples was $65 \%$.

The faecal recovery of total neutral sugars was similar to the results reported by Nyman et al. (1986) using apple-pulp fibre. The KL fraction of the IDF residue was totally resistant to bacterial degradation, which concurs with earlier studies in rats (Nyman \& Asp, 1982). Woods \& Gorbach (1986) reported that, while pectins were almost totally degraded $(90-100 \%)$ and other fibre constituents were partially degraded, lignin was completely resistant to degradation by the human intestinal flora. This is in agreement with our results in rats. A good correlation has been found between the rat model and human studies (Nyman et al. 1986), showing that this experimental model is useful to predict fermentative breakdown and bulking capacity of apple-pulp DF in humans.

Of the phenolic compounds, CT seem to be partially degraded in the intestinal tract, since only $68.6 \%$ of the ingested tannins were recovered in faeces (Table 6 ). The soluble polyphenols were more extensively degraded than CT $(85.9 \%)$. Compared with the fermentation of DF fractions, soluble polyphenols were degraded to the same extent as SDF, whereas CT were more resistant to degradation than IDF.

No information on faecal recovery of CT was available in the literature, and whether tannins can be absorbed through the intestinal wall or not is still an open question. Simple phenols, such as catechin, or low-molecular-weight polyphenols, such as tannic acid, are known to be degraded in the upper intestinal tract and utilized by the microflora in the hind-gut of rats (Nyman \& Björck, 1989), but it is not known whether large tannin macromolecules can get through gastrointestinal tissues or not (Singleton, 1981).

Faecal $\mathrm{N}$ excretion was significantly increased when DF was added to the basal diet, while the small differences found in urinary $\mathrm{N}$ excretion were not significant. Hence, increased faecal $\mathrm{N}$ excretion was not compensated for by a decrease in urinary $\mathrm{N}$ excretion, which does not agree with previous findings in humans (Calloway \& Krestch, 1978; Kelsay et al. 1978) as well as in animals (Nomani et al. 1979; Fairweather-Tait et al. 1983) using other DF sources. However, other authors did not find a full compensation for the increase in faecal $\mathrm{N}$ by the urinary $\mathrm{N}$ decrease (Gallaher \& Schneeman, 1986).

In the present work, we have found that with the same protein intake, faecal $\mathrm{N}$ excretion was higher in the fibre-fed group. The increased faecal $\mathrm{N}$ excretion may be due to the influence of either DF or CT on the dietary protein utilization and on the endogenous $\mathrm{N}$ metabolism.

It has been shown that DF increases faecal $\mathrm{N}$ excretion when it is fed as a purified preparation (Greenberg, 1976; Cummings et al. 1979) or when it is derived from different sources (Cummings et al. 1976; Calloway \& Kretsch, 1978; Kelsay et al. 1978; Anonymous, 1984). Several suggestions have been made to explain the manner in which fibre brings about this effect: (1) the protein of fibre itself is undigested and excreted in faeces (Saunders \& Betschart, 1980); (2) the dietary protein is not completely absorbed because of the increased colonic volume due to the addition of fibre (Bender et al. 1979); (3) the fibre decreases the activity of proteolytic enzymes such as trypsin (EC 3.4.21.4) and chymotrypsin (EC 3.4.21.1) Schneeman, 1978; Stephen, 1987).

All these mechanisms involve a decrease in the dietary protein digestibility. However, the increased faecal $\mathrm{N}$ excretion may also be due to an increase in the endogenous $\mathrm{N}$ excretion. It is suggested that DF stimulates mucosal cell proliferation (Southgate, 1973; FairweatherTait et al. 1983) increasing the endogenous protein production, although most of the extra protein would be available for reabsorption (Fairweather-Tait et al. 1983). Sandaradura et al. (1986) reported an increased excretion of endogenous $\mathrm{N}$ resulting from increased mucosal cell turnover when high-fibre diets were fed to rats. Another explanation of the 
increased faecal $\mathrm{N}$ output arises from the effect of fibre on faecal bacterial mass, which implies an increase in $\mathrm{N}$ excretion from the intestinal microflora (Stephen \& Cummings, 1990).

The effect of polyphenols on the excretion of faecal $\mathrm{N}$ can also be explained by mechanisms that involve a decrease in the digestion and absorption of dietary protein, and by mechanisms that involve an increase in the excretion of endogenous $N$ (Shahkhalili et al. 1990).

Three mechanisms for decreased dietary protein digestibility by tannins have been suggested (Hughes, 1989): (1) reduced protein digestion in the stomach by reducing acid production; (2) reduced protein bioavailability by precipitation of dietary protein bound to tannin; (3) reduced digestion in the small intestine caused by binding and inactivation of digestive enzymes.

Different authors (Eggum et al. 1983; Horigome et al. 1988) point out a significant increase in faecal $\mathrm{N}$ excretion as a consequence of the interaction between polyphenols and dietary protein. Our results (Table 5) show that a large amount of the ingested polyphenols are excreted in faeces, agreeing with in vitro experiments (Saura-Calixto, 1988; Goñi et al. 1989; Saura-Calixto et al. 1990, 1991) which show that, after treatment with digestive enzymes ( $\alpha$-amylase, protease and amyloglucosidase), a residue containing both polyphenols and proteins remains as the result of the formation of indigestible tannin-protein complexes (Aw \& Sawson, 1985; Barroga et al. 1985) and of enzymic inhibition phenomena (Griffiths \& Moseley, 1980).

The possible effect of polyphenol on the endogenous $\mathrm{N}$ excretion cannot be ignored. Comparison of the amino acid profile of faecal material and dietary protein shows large differences between rats fed on tannin diets (Butler, 1989) and those that were not fed such diets. It has also been reported that, sometimes, tannin consumption causes a greater total $\mathrm{N}$ excretion than the total amount of $\mathrm{N}$ ingested (Singleton, 1981). Therefore, it is clear that endogenous $\mathrm{N}$ is involved in the rise in $\mathrm{N}$ excretion due to tannin intake. Nevertheless, whether this $\mathrm{N}$ comes from an increased cellular turnover or from an increase in digestive secretions is not known. Mitjavila et al. (1977) reported an increased excretion of mucoprotein, sialic acid and glucosamine in the faeces. Leguminous diets, which contain appreciable amounts of polyphenols, have been shown to increase the rate of mucosal cell turnover in rats (Sandaradura et al. 1986).

Therefore, both compounds, DF and tannins, are involved in the increased faecal $\mathrm{N}$ excretion caused by the apple pulp. Further investigations are necessary in order to determine the mechanism by which this effect is produced as well as which compound produces such an effect and to what extent it carries it out.

The financial support of the Spanish Comisión Interministerial de Ciencia y Tecnología (Project ALI 89: 0551) is acknowledged.

\section{REFERENCES}

Anonymous (1984). The effect of fiber on protein digestibility. Nutrition Review 42, 2324.

Aw. T. L. \& Swanson, B. G. (1985). Influence of tannin on Phaseolus vulgaris protein digestibility and quality. Journal of Food Science 50, 67-71.

Barroga, C. F., Laurena, A. C. \& Mendoza, E. M. T. (1985). Effect of condensed tannins on the in vitro protein digestibility of mung bean (Vigna radiata (L.) Wilzeck). Journal of Agricultural and Food Chemistry 33, $1157-1159$.

Bender, A. E., Mohammadiha, H. \& Alams, K. (1979). Digestibility of legumes and available lysine content. Qualitas Plantarum 29, 219-226.

Bingham, S. (1985). Dietary fibre intakes: Intake studies, problems, methods and results. In Dietary Fibre. Fibre Depleted Foods and Disease', pp. 77-104 [H. Trowell, D. Burkitt and K. Heaton, editors]. London: Academic Press. 
Bingham, S. (1987). Definitions and intakes of dietary fibre. American Journal of Clinical Nutrition 45, 1226 1231.

Butler, L. G. (1989). Effects of condensed tannin on animal nutrition. In Chemistry and Significance of Condensed Tannins, pp. 391-402 [R. W. Hemingway and J. J. Karchesy, editors]. New York: Plenum Press.

Calloway, D. H. \& Kretsch, M. J. (1978). Protein and energy utilization in men given a rural Guatemalan diet and egg formulas with and without added oat bran. American Journal of Clinical Nutrition 31, 1118-1126.

Cummings, J. H., Hill, M. J., Jenkins, D. J. A., Pearson, J. R. \& Wiggins, H. S. (1976). Changes in faecal composition and colonic function due to cereal fibre. American Journal of Clinical Nutrition 29, 1468-1473.

Cummings, J. H., Southgate, D. A. T., Branch, W. J. \& Wiggins, H. S. (1979). The digestion of pectin in the human gut and its effects on calcium absorption and large bowel function. British Journal of Nutrition 47, 477-485.

Eastwood, M. (1987). Dietary fiber and the risk of cancer. Nutrition Reviews 45, 193-198.

Eggum, B. O., Pedersen, B. \& Jacobsen, I. (1983). The influence of dietary tea, coffee and cocoa on protein and energy utilization of soya bean meal and barley in rats. British Journal of Nutrition 50, 197-205.

Fairweather-Tait, S. J., Gee, J. M. \& Johnson, I. T. (1983). The influence of cooked kidney beans (Phaseolus vulgaris) on intestinal cell turnover and faecal nitrogen excretion in the rat. British Journal of Nutrition 49, $303-312$.

Fibre-90 (1990). Chemical and Biological Aspects of Dietary Fibre. Workshop: Sources and Processing of Dietary Fibre. [D. A. T. Southgate, K. Waldron, I. T. Johnson and G. R. Fenwick, editors]. Cambridge: Royal Society of Chemistry.

Gallaher, D. \& Schnceman, B. O. (1986). Effect of dietary fiber on protein digestibility and utilization. In Handbook of Dietary Fiber in Human Nutrition, pp. 143-164 [G. A. Spiller, editor]. Boca Raton, Florida: CRC Press.

Goñi, I., Torre, M. \& Saura-Calixto, F. (1989). Determination of dietary fibre in cider wastes. Comparison of methods. Food Chemistry 33, 151-159.

Greenberg, C. (1976). Studies on the fibre in human diets and its effects on the absorption and digestion of other nutrients. PhD Thesis, University of Cambridge.

Griffiths, W. \& Moseley, G. (1980). The effect of diets containing field beans of high and low polyphenolic content on the activity of digestive enzymes in the intestine of rats. Journal of the Science of Food and Agriculture 31, $255-259$.

Horigome, T., Kumar, R. \& Okamoto, K. (1988). Effects of condensed tannins prepared from leaves of fodder plants on digestive enzymes in vitro and in the intenstine of rats. British Journal of Nutrition 60, $275-285$.

Hughes, J. L. (1989). Effect of dietary fiber and tannins on protein nutritive value in the common bean (Phaseolus vulgaris). PhD Thesis, Washington State University.

Kelsay, J. L., Behall, K. M. \& Prather, E. S. (1978). Effect of fiber from fruits and vegetables on metabolic responses of human subjects, I. Bowel transit time, number of defecations, fecal weight, urinary excretion of energy and nitrogen and apparent digestibilities of energy, nitrogen and fat. American journal of Clinical Nutrition 32, 1149-1153.

Kumar, R.\& Singh, M. (1984). Tannins : their adverse role in ruminant nutrition. Journal of Agricultural and Food Chemistry 32, 447-453.

Mitchell, H. H. (1923-24). A method of determining the biological value of protein. Journal of Biological Chemistry 5, 883-903.

Mitjavila, S., Lacombe, C., Carrera, G. \& Derachc, R. (1977). Tannic acid and oxidized tannic acid on the functional state of rat intestinal epithelium. Joumal of Nutrition 107, 2113-2121.

Nomani, M. Z., Fashandi, E. F., Davis, G. K. \& Bradac, C. J. (1979). Influence of dietary fibre on the growth and protein metabolism of the rat. Journal of Food Science 44, 745-747.

Nyman, M. \& Asp. N.-G. (1982). Fermentation of dictary fibre composition in the rat intestinal tract. British Journal of Nutrition 47, 357-366.

Nyman, M. \& Asp, N.-G. (1985). Bulk laxatives: their dietary fibre compsotion, degradation, and faecal bulking capacity in the rat. Scandinavian Journal of Gastroenterology 20, 887-895.

Nyman, M., Asp, N.-G., Cummings, J. \& Wiggins, H. (1986). Fermentation of dietary fibre in the intestinal tract: comparison between man and rat. British Journal of Nutrition 55, 487-496.

Nyman, M. \& Bjorck, I. M. (1989). In vivo effects of phytic acid and polyphenols on the bioavailability of polysaccharides and other nutrients. Journal of Food Science 54, 1332-1335.

Nyman, M., Schweizer, T. F., Tyren, S., Reimann, S. \& Asp, N.-G. (1990). Fermentation of vegetable fiber in the intestinal tract of rats and effects on fecal bulking and bile acid excretion. Journal of Nutrition 120, 459-466.

Oh, H. I., Hoff, J. E. \& Haff, L. A. (1985). Immobilized condensed tannins and their interaction with protein. Journal of Food Science 50, $1652 \cdots 1654$.

Park, C. S. \& Harrold, R. L. (1983). Effects of dietary protein and fiber on growth and selected cholesterol responses of rats. Annals of Nutrition and Metabolism 27, 137-144.

Prosky, L., Asp, N.-G., Schweizer, T. F., DeVries, J. W. \& Furda, I. (1988). Determination of insoluble, soluble and total dietary fibre on foods and food products: interlaboratory study. Journal of the Association of Official Analyical Chemists 71, 1017-1023.

Reed, J. D., McDowell, R. E., Van Soest, P. J. \& Horvath, P. J. (1982). Condensed tannins: a factor limiting the use of cassava forage. Journal of the Science of Food and Agriculture 33, 213-220. 
Sandaradura, S. S., Bender, A. E. \& Grahan, P. B. (1986). Effect of high fibre diets on faecal DNA and mucosal cell proliferation in the rat. Proceedings of the Nutrition Society 46, 97A.

Saunders, R. M. \& Betschart, A. A. (1980). The significance of protein as a component of dietary fibre. American Journal of Clinical Nutrition 33, 960-961.

Saura-Calixto, F. (1988). Effect of condensed tannins in the analysis of dietary fibre in carob pods. Journal of Food Science 53, 1769-1771.

Saura-Calixto, F., Goñi, I., Mañas, E. \& Abia, R. (1990). Condensed tannins and resistant protein as dietary fibre constituents. Fibre-90. Chemical and Biological Aspects of Dietary Fibre, pp. 109-112 [D. A. T. Southgate, K. Walden, I. T. Johnson and G. R. Fenwick, editors]. Cambridge: Royal Society of Chemistry.

Saura-Calixto, F., Goñi, 1., Mañas, E. \& Abia, R. (1991). Klason lignin, condensed tannins and resistant protein as dietary fibre constituents: determination in grape pomaces. Food Chemistry 39, 299-309.

Schneeman, B. O. (1978). Effect of plant fibre on lipase, trypsin and chymotrypsin activity. Journal of Food Science 43, 634-635.

Scott, R. W. (1979). Colorimetric determination of hexuronic acids in plant materials. Analytical Chemistry 51, 936-941.

Shahkhalili, Y., Finot, R. A., Hurrel, R. \& Fern, E. (1990). Effects of food rich in polyphenols on nitrogen excretion in rats. Journal of Nutrition 120, 346-352.

Singleton, V. L. (1981). Naturally occurring food toxicants: phenolic substances of plant origin common in foods. Advances in Food Research 27, 149-242.

Snedecor, G. W. \& Cochran, W. G. (1987). Statistical Methods, 7th ed., pp. 221-222. Ames, Iowa: Iowa State University Press.

Southgate, D. A. T. (1973). Fiber and other unavailable carbohydrates and their effects on the energy value of the diet. Proceedings of the Nutrition Society 32, 131.

Southgate, D. A. T. (1976). Selected methods. In Determination of Food Carbohydrates, pp. 108-109. London: Applied Sciences Publishers Ltd.

Spilier, G. A. (1986). Suggestion for a basis on which to determine a desirable intake of dietary fibre. In Handbook of Dietary Fiber in Human Nutrition, pp. 281-284 [G. A. Spiller, editor]. Boca Raton, Florida: CRC Press.

Stephen, A. M. (1987). Dietary fibre and colonic nitrogen metabolism. Scandinavian Journal of Gastroenterology 22, $110-115$.

Stephen, A. M. \& Cummings, J. H. (1980). Mechanism of action of dietary fibre in the human colon. Nature 284, $283-284$.

Swain, T. \& Hillis, W. E. (1959). The phenolic constituents of Prunus domestica. 1. The quantitative analysis of phenolic constituents. Joumal of the Sciences of Food and Agriculture 10, 63-68.

Woods, M. N. \& Gorbach, S. L. (1986). Influence of fiber on the ecology of the intestinal flora. In Handbook of Dietary Fiber in Human Nutrition, pp. 289-297 [G. A. Spiller, editor]. Boca Raton, Florida: CRC Press.

Würsch, P. (1979). Influence of tannin-rich carob pod fiber on the cholesterol metabolism in the rat. Journal of Nutrition 109, 685-692. 